\title{
RZECIW BOLSZEWIKOM, MASONOM, ŻYDOM... PUBLICYSTYCZNE ZMAGANIA ALEKSANDRA BOCHEŃSKIEGO W OKRESIE „BUNTU MŁODYCH” I „POLITYKI”
}

Jan Sadkiewicz http://orcid.org/0000-0001-6522-9509

Uniwersytet Jagielloński w Krakowie

\author{
ABSTRACT \\ AGAINST THE BOLSHEVIKS, FREEMASONS AND JEWS... \\ ALEKSANDER BOCHEŃSKI'S ESSAYISTIC STRUGGLE IN THE BUNT \\ $M Ł O D Y C H$ AND POLITYKA PERIOD
}

In the 1930s, Aleksander Bocheński was one of the co-authors of the editorial lines of the Bunt Młodych and Polityka magazines, their hallmark being a fierce fight with their journalistic opponents. Beside the core texts dedicated primarily to minorities and the economic policy, his essayistic struggles were one of the main fields of his journalistic activity in that period, and are the main topic of this article. Bocheński was particularly bellicose in his fight against the liberal periodical Wiadomości Literackie and left-wing journals, which he accused of such things as being pro-Bolshevik and pursuing changes in the political system which, in his view, would weaken the state. Throughout the decade, one can observe a gradual fading of Bocheński's initial optimistic conviction that the young advocates of Poland as a great power would rule the day, as well as his growing concern with the continuing influence of left-liberal circles, which not only found expression in his criticism of the government policy in almost every area, but also prepared the ground for a profound ideological change which Bocheński experienced during the war.

Key words: Aleksander Bocheński, Bunt Młodych, Polityka, the press in the interwar Poland.

Słowa kluczowe: Aleksander Bocheński, „Bunt Młodych”, „Polityka”, prasa II RP.

Aleksander Bocheński (1904-2001), sławny przede wszystkim jako autor Dziejów glupoty w Polsce, wywodził się ze środowiska, które śmiało można nazwać kuźnią kadr polskiej publicystyki politycznej i społecznej XX wieku. Na łamach „Buntu Młodych” (od 1937 r. „Polityki”) pisarski warsztat kształtowali, obok braci 
Bocheńskich, bracia Pruszyńscy, bracia Zbyszewscy, Stanisław Stomma, Stefana Kisielewski, Konstanty Łubieński, Konstanty Turowski czy Jan Frankowski, by wymienić tylko kilku. Losy członków tej grupy potoczyły się różnie: niektórzy odnaleźli swoje miejsce w dyplomacji PRL (Józef Winiewicz, Piotr Dunin-Borkowski, Bohdan Łączkowski, Ksawery Pruszyński), inni, z Jerzym Giedroyciem na czele, odegrali niepoślednią rolę w kształtowaniu emigracji polskiej po 1945 roku. Nie będzie więc przesadą stwierdzenie, że odcisnęli na swojej epoce piętno większe, niż mógłby na to wskazywać ich punkt startu - niszowe pismo akademickie.

Bohater niniejszego tekstu należał, obok Giedroycia, swego brata Adolfa, Pruszyńskich i Frankowskiego, do nieformalnej rady decydującej o linii pisma ${ }^{1}$ (po odejściu Ksawerego nazywanej „grubą piątką"2) i jego pozycja w tym gronie (sądząc choćby z tonu, jakim w listach pouczał „Misia” Pruszyńskiego) nie była niska ${ }^{3}$. Mimo to jego dorobkowi z tego okresu poświęcano dotąd niewiele uwagi $-\mathrm{z}$ dwóch, jak się wydaje, zasadniczych względów. Po pierwsze, przedwojenna publicystyka Aleksandra pozostaje w cieniu twórczości jego młodszego brata Adolfa, postrzeganego jako czołowy ideolog „Buntu...”, a do tego otoczonego nimbem bohaterskiej śmierci. Po drugie, w przypadku Aleksandra większe zainteresowanie budziła działalność powojenna, przede wszystkim udział w powołaniu ugrupowania katolików deklarujących chęć współpracy z rządem i sojuszu z ZSRR ${ }^{5}$ czy tezy i recepcja Dziejów glupoty $w$ Polsce ${ }^{6}$. W kontekście publicystyki powojennej podejmowano próby szerszego spojrzenia na jego wizję polskości czy realizmu politycznego ${ }^{7}$. Na głębszą analizę myśli politycznej Bocheńskiego nie było miejsca w pracach poświęconych

1 M. Kró1, Style politycznego myślenia. Wokót „Buntu Młodych” i „Polityki”, Paryż 1979, s. 13; P. Libera, Ocena polityczna grupy „Polityki” przez Oddziat II Sztabu Glównego w 1938 r., „Zeszyty Historyczne. ZNUJ" 2010, z. 171, s. 146.

2 ARB, Luźne wspomnienia Aleksandra Bocheńskiego o swoim bracie Adolfie, mps, [b.d.], s. 6.

3 Niewykluczone też, że wpłynął na odejście Ksawerego, który, w mniemaniu Aleksandra, sprzeniewierzył się ideom reprezentowanym przez „Bunt...” (o czym dalej).

4 R. Habielski, Dokad nam iść wypada? Jerzy Giedroyć od „Buntu Młodych” do „Kultury”, Warszawa 2006, s. 23.

5 R. Mozgol, Ryzykowna gra. Jak Aleksander Bocheński przyczynit się do powstania „Dziś i Jutro”, „Biuletyn IPN” 2007, nr 4 (75), s. 84-92.

${ }^{6}$ Bezpośrednio po publikacji książkę recenzowali m.in.: S. Kieniewicz, Nowy sąd nad historia, „Dziś i Jutro”, nr 25 (82), 22 V 1947 r., s. 1-2; P. J a si en i c a, Cień Machiawela, „Tygodnik Powszechny”, nr 31 (124), 3 VIII 1947 r.

A. Wierzbicki, Wszystkiemu winni sq historycy. W kręgu myśli historycznej i politycznej Aleksandra Bocheńskiego i Andrzeja Wasilewskiego, w: Gra i konieczność. Zbiór rozpraw z filozofii historii $i$ historii historiografii, red. G. Dominiak, J. Ostoja-Zagórski, W. Wrzosek, Bydgoszcz 2005, s. 155-161; W. Wendland, Katon w ,krainie wielkich blaznów”. Aleksandra Bocheńskiego wizja polskości [w:] Marzyciele i realiści. O roli tradycji w polskiej myśli politycznej od upadku powstania styczniowego do XXI wieku, red. T. Sikorski, A. W ą tor, Szczecin 2009, s. 521-534; J. S a d ki e w ic z, Schemat sojuszu z silniejszym mocarstwem - Aleksander Bocheński od koncepcji proniemieckiej do koncepcji prosowieckiej [w:] Między sercem a rozumem. Romantyzm i realizm w polskiej myśli politycznej, red. A. Citkowska-Kimla [i in.], Kraków 2017, s. 283-294. 
całemu środowisku „Buntu...”8 ani tym bardziej we wspomnieniach przyjaciół’, pozostaje on też na marginesie zainteresowania badaczy zajmujących się wybranymi aspektami przedwojennej myśli politycznej ${ }^{10}$ czy dziejami konserwatyzmu w Polsce $^{11}$. Niniejszym artykułem chciałbym częściowo wypełnić tę lukę.

Spektrum zainteresowań Bocheńskiego było szerokie. Jego domeną w grupie „Buntu...” była polityka mniejszościowa, ze szczególnym uwzględnieniem kwestii ukraińskiej. Poświęcił jej swoją jedyną, jeśli nie liczyć debiutanckiej broszury ${ }^{12}$, przedwojenną książkę: wydany w maju 1938 roku Problem polsko-ukraiński w Ziemi Czerwieńskiej ${ }^{13}$ (była to $\mathrm{w}$ zasadzie praca zbiorowa, napisana wspólnie ze Stanisławem Łosiem i Włodzimierzem Bączkowskim, niemniej to Aleksander wypełnił prawie 200 z przeszło 240 stron dzieła). Problem białoruski nie absorbował Aleksandra w takim stopniu, natomiast stałym elementem jego publicystyki była kwestia żydowska. Po sprawach mniejszościowych najwięcej uwagi poświęcał ekonomii i polityce zagranicznej, nie stronił wreszcie od dyskusji na temat ustroju i ideologii odrodzonej Rzeczypospolitej.

$\mathrm{Na}$ całościową analizę przedwojennej publicystyki Bocheńskiego nie ma tutaj miejsca; celem tego tekstu jest jedynie rzucenie pewnego światła na postawę ideową trzydziestoparoletniego Aleksandra - poprzez przedstawienie go jako polemisty. „Pokaż mi swoich wrogów, a powiem ci, kim jesteś” - oto myśl, która przyświeca poniższym rozważaniom, a tytułowe „zmagania” należy rozumieć dosłownie - jako „polemiki”, „walki” - a nie jako synonim aktywności publicystycznej in toto.

Spojrzeniu z tej perspektywy sprzyja znaczenie, jakie do prasowych utarczek przywiązywano w grupie „Buntu...”. Skłonność do polemik Rafał Habielski podaje za dowód niezależności, odwagi i pewności siebie młodych publicystów - a można uznać ją też za świadomie przyjętą strategię budowania własnej marki. Mocarstwowcy (takim mianem, od ich pierwszej organizacji - Myśli Mocarstwowej, określane jest także to środowisko) atakowali ostro, niejednokrotnie nie przebierając $\mathrm{w}$ słowach, bez kompleksów wobec potentatów rynku tygodników, mimo że wyraźnie ustępowali im popularnością i wysokością nakładu ${ }^{14}$. Jeśli w polityce zagranicznej

8 M. Król, op. cit.; R. Habielski, op. cit.

9 J. Giedroyć, Autobiografia na cztery ręce, Warszawa 1994; M.A. Supruniuk, Uporzadkować wspomnienia. Nieautoryzowane rozmowy z Jerzym Giedroyciem, Torun 2011; M. Pruszyńs ki, $W$ dziewięćdziesiąa rocznicę urodzin Aleksandra Bocheńskiego, „Zeszyty Historyczne. ZNUJ” 2000, z. 134, s. 162-175; M. Pruszyński, Migawki wspomnień, Warszawa 2002.

10 M. Kornat, Polska szkoła sowietologiczna 1930-1939, Kraków 2003; G. Zackiewicz, Polska myśl polityczna wobec systemu radzieckiego 1918-1939, Kraków 2004; R. To m czy k, Myśl mocarstwowa. Z dziejów młodego pokolenia II Rzeczypospolitej, Szczecin 2008.

11 B. Szlachta, Z dziejów polskiego konserwatyzmu, Wydawnictwo Dante, Kraków 2000; B. Ga1ka, Konserwatyści w Polsce lat 1935-1939, wyd. uzup. i popr., Torun 2013.

12 A. Bocheński, A.M. Bocheński, Tendencje samobójcze narodu polskiego, Lwów 1925.

13 A. Bocheński, S. Łoś, W. Bączkowski, Problem polsko-ukraiński w Ziemi Czerwieńskiej, Warszawa 1938.

14 R. Habielski, op. cit., s. 24. 
kazali przyjmować regułę koncentracji na jednym przeciwniku ${ }^{15}$, to w publicystycznych zmaganiach kierowali się zasadą wręcz odwrotną.

„Autor tej krytyki jest zamiłowanym polemistą i nie potrafi wziąć pióra do ręki, jak tylko po to, by czyjeś myśli zwalczać"16 - napisze później Bocheński w swoim opus magnum. W jakim stopniu takie stanowisko zostało ukształtowane przez przyjaciół i współpracowników we wczesnym okresie twórczości pisarskiej, a w jakim było wianem wniesionym przez Aleksandra i jego braci do grupy „Buntu...” i „Polityki”, niepodobna rozstrzygnąć. Dość powiedzieć, że w latach 30. XX wieku Bocheński ze swym polemicznym zapałem trafił we właściwe miejsce - na łamy pisma, które ataki na publicystycznych przeciwników uczyniło jednym ze swoich znaków rozpoznawczych.

Obiektem krytyki były pisma rządowe, liberalne, lewicowe, narodowe, frontmorżowe; mimo ideowych korzeni młodych mocarstwowców na specjalne rewerencje nie mogli też liczyć (może poza jednym Mackiewiczem) „starzy” konserwatyści. Dodajmy tytułem dygresji, że choć większość zarówno współczesnych, jak i późniejszych komentatorów zalicza grupę „Buntu...” do nurtu myśli konserwatywnej (ewentualnie młodokonserwatywnej lub neokonserwatywnej), sami zainteresowani składali w tej sprawie sprzeczne deklaracje, a co więcej - miewali problem z odpowiedzią na pytanie, co właściwie rozumieją przez konserwatyzm ${ }^{17}$. Sam Aleksander Bocheński „przedwojenne” etykiety uznawał za w zasadzie mało istotne dla roztrząsania kluczowych problemów państwa ${ }^{18}$, i w innym miejscu dostrzegał linię zasadniczego sporu o kształt Polski. Domagał się radykalnego zerwania ze schematami myślenia wypracowanymi przez pokolenia wychowane w niewoli, a nadzieje na stworzenie ideologii dla odrodzonej Rzeczypospolitej pokładał w młodzieży. Udziału w tym wysiłku nie odmawiał z góry nikomu, bez względu na przynależność organizacyjną czy partyjną, a młody socjalista bądź ludowiec mógł mu być bliższy niż konserwatysta starszego pokolenia ${ }^{19}$.

„Można powiedzieć - pisze prof. Habielski - że «Bunt» i «Polityka» były w stanie wojny niemal ze wszystkimi" ${ }^{20}$. W szerokim froncie ideowych przeciwników Aleksander dostrzegał jednak jedno pismo, które zwalczał ze szczególną zaciekłością i w którego światopoglądzie widział dokładne przeciwieństwo wartości łączących nie tylko autorów „Buntu...”, ale całe młode pokolenie. „Na każdy argument dobry dialektyk znajdzie kontrargument - pisał w 1934 roku - na każdy cytat znaleźć można cytat inny. Ale na to głębokie, instynktowne, a więc niezłomne przekonanie całej

15 A.M. Bocheński, Granice relatywizmu politycznego, „Bunt Młodych”, nr 25-26 z 20 XII 1935 r. - 5 I 1936 r., s. 4.

16 A. Bocheńs ki, Dzieje glupoty w Polsce. Pamflety dziejopisarskie, Warszawa 1947, s. 110.

17 R. Habielski, op. cit., s. 76-78, 87, 89.

18 A. Bocheński, Notatki polemiczne. „Dziennik Poranny”, „Słowo”, nr 184 z 6 VII 1937 r., s. 3.

19 Zob. m.in. A. Bocheńs ki, Czerwienimy się za Was Panowie..., „Bunt Młodych”, nr 36, styczeń 1933 r., s. 1; idem, Podkreślania i niedomówienia Ryszarda Piestrzyńskiego, „Bunt Młodych” nr 7 (56), z 20 IV 1934 r., s. 1; idem, Inteligencji polskiej twardy zakon, „Polityka”, nr 21-22 (135-136) z 15 VIII 1937 r.; idem, Problem młodzieży rzadowej, „Polityka”, nr 25 (139), z 10 X 1937 r., s. 3; idem, Misja dziejowa Pana Frycza, „Polityka”, nr 8 (153), z 25 III 1938 r., s. 1.

20 R. Habielski, op. cit., s. 24. 
Młodej Polski, że «Wiadomości [Literackie]» są czymś obcym i wrogim, nie ma żadnej rady, żadnego argumentu, żadnego cytatu"'21.

Antykatolickie, antynarodowe, antymilitarne, komunizujące, wyprute z poczucia polskiej racji stanu - takie było w oczach Bocheńskiego pismo kierowane przez Mieczysława Grydzewskiego. Aleksander składał ironiczny hołd jednocześnie geniuszowi i bezczelności redaktora, którego metoda - demaskował na łamach „Buntu...”polegała na budowaniu polskiego parawanu dla antypolskiej działalności ${ }^{22}$. Dzięki umiejętnej dystrybucji prestiżu i pieniędzy Grydzewski ściągał do „Wiadomości...” prawdziwych Polaków (przy czym nie chodziło tu o kryterium rasowe, Bocheński rozumiał przez to raczej ludzi kierujących się polskim interesem narodowym), prawdziwych katolików, przedstawicieli prawdziwej elity intelektualnej, którzy służyli jednak tylko za pozór bezstronności i zasłonę dla - mówiąc słowami Aleksandra „szajki intelektualizujących, piszących, komunizujących żydków, którzy nie potrafiwszy się przejąć naszą narodową kulturą zatruwają ją brakiem charakteru, brakiem zasad, brakiem religii, sybarytyzmem, pacyfizmem i nihilizmem, którzy płaszczą się przed masą, kiedy jest demokracja, przed dyktaturą, gdy dyktatura” („Ile razy piszemy «żydki», o nich tylko myślimy"23 - wyjaśniał Bocheński, podkreślając swój mniej lub bardziej życzliwy stosunek do syjonistów, ortodoksów czy Polaków wyznania mojżeszowego). Do numeru antymilitarnego Grydzewski zaprosi zawsze jakiegoś wojskowego, propagandę bezbożniczą osłaniać będzie swoim nazwiskiem jakiś katolik, w numerze komunizującym znajdzie się jakiś monarchista lub konserwatysta ${ }^{24}$. Bocheński przestrzegał, by nie dawać się zwieść tym polskim i katolickim pozorom, za którymi kryje się konsekwentna linia antynarodowa i antyreligijna, o której decydują stali publicyści pisma ze Słonimskim, Boyem-Żeleńskim, Krzywicką i Hulką-Laskowskim na czele ${ }^{25}$.

Istotę ideowego sporu z „Wiadomościami...” Aleksander najpełniej wyłożył w opublikowanym w 1934 roku Liście do Ksawerego Pruszyńskiego, w którym odpowiadał na podniesione przez przyjaciela argumenty w obronie tygodnika.

Stosunkowo wiele miejsca zabrała w nim sprawa stosunku do religii, choć Bocheński zaznaczał, że „Bunt...” nie jest pismem sodalicyjnym, jego publicystami nie kieruje żarliwość religijna, a czytelnicy nie sięgają po nie dla rozważania problemów wiary i moralności. Jesteśmy jednak katolikami - stwierdzał - i nie możemy przechodzić obojętnie wobec ataków na to, co dla nas święte. Przyznawał Ksaweremu, że „Wiadomości...” nie są radykalnie antykatolickie - ale to właśnie czyni je stokroć groźniejszym przeciwnikiem. „Od kiedy to w Polsce - pytał - atak frontowy jest bardziej niebezpieczny od obejścia?!”. Dla duszy Polaka nie są groźne dziwaczne napaści i bluźnierstwa w stylu „Wolnomyśliciela”, ale atmosfera pogardy i lekceważenia dla spraw religijnych roztaczana przez pismo Słonimskiego i Boya. „Każdy pisarz

${ }^{21}$ A. Bocheński, Oskarżamy ,,Wiadomości Literackie”. List do Ksawerego Pruszyńskiego, „Bunt Młodych", nr 5 z 19 III 1934 r., s. 1-2.

22 Idem, Zygzakiem przez prase, „Bunt Młodych”, nr 12-13 z 20 VI 1935 r., s. 12.

23 Idem, Nasze nie ich..., „Bunt Młodych”, nr 43 z 15 VII 1933 r.

24 Idem, Zygzakiem przez prasę, s. 12.

25 Idem, Oskarżamy ,Wiadomości Literackie”, s. 1-2. 
katolicki piszący w «Wiadomościach...»-konkludował Bocheński - jest poputczikiem, wierzącym, że jego artykuł, zasadniczo przygodny, zrobi więcej dobrego, niż dziesiątki artykułów stałych współpracowników zrobią złego"26.

Bocheński odmawiał „Wiadomościom...” zasług na polu podnoszenia poziomu intelektualnego społeczeństwa, przywołanych przez Pruszyńskiego jako „preparowanie literatury do poziomu zwykłego inteligenta”. „Co to za inteligenci, dla których trzeba literaturę preparować - pytał Aleksander - i co to za pismo, które preparuje literaturę zamiast preparować czytelnika?"27.

Nie negował talentów publicystów zebranych przez Grydzewskiego, ale „Bunt...” - deklarował - nie da się zastraszyć nazwiskami, szczególnie gwiazd starego pokolenia. Była to kwestia hierarchii wartości: „Religia i Polska to nasze kryteria naczelne - pisał Aleksander. - Droga do potęgi, to nasza droga - jedyna. Jak śmieszne i jak małe wydają się teraz jedyne atuty naszych przeciwników - ich talenty! [...] Gdy ktoś bije w fundamenty myślenia religijnego, moralnego, narodowego, imperialistycznego, nie przychodzi mi na myśl wołać, że on ma rację, bo pisze dobrym stylem, ma dobre dowcipy, wspaniałe reprodukcje obrazów. Może, gdyby główną pasją mego życia była literatura, dowcipy, grafika, myślałbym inaczej! Ale nie myślę inaczej, ani Ty - zwracał się do Ksawerego - nie myślisz inaczej, ani nikt z naszych" ${ }^{28}$. To, co drugorzędne dla autorów „Buntu...”, miało jednak olbrzymi wpływ na masy, wobec czego nie można było pozwolić sobie na demobilizację. „O «Wolnomyślicielu» można milczeć - kończył Bocheński - o «Wiadomościach...» trzeba pisać”29.

Ostatnim i uznanym przez Aleksandra za najsilniejszy argumentem Pruszyńskiego było twierdzenie, że przy wszystkich swoich wadach „Wiadomości...” są jednak dla Polaków oknem na Zachód, oddalającym ich od „parafiańskości i dzikości” Wschodu, a przez to są potrzebne i pożyteczne. Bocheński w odpowiedzi zauważał, że dychotomia Wschód-Zachód jest pewną symplifikacją (choć z drugiej strony dodajmy na marginesie - słowo „wschodni” miało w jego tekstach przedwojennych wydźwięk zdecydowanie negatywny), przede wszystkim jednak stwierdzał, że „Wiadomości...” z kultury zachodnioeuropejskiej czerpią tylko to, „,o zdegenerowane, zgniłe, pozbawione wielkiego tchnienia twórczości i potęgi” (np. pornografię ${ }^{30}$ ). Z prawdziwymi wartościami Zachodu, katolickimi i rzymskimi, toczą zaś otwartą walkę, prowadząc jednocześnie mniej lub bardziej jawną propagandę promoskiewską i probolszewicką (Hulkę-Laskowskiego, zachwycającego się oferowanym przez Rosję sowiecką „miłym wrażeniem wyzwolenia z powijaków umarłych mitologii” pytał, dlaczego, po prostu się tam nie przeniesie $\left.{ }^{31}\right)$. Takie „okno na Zachód” prędzej

\footnotetext{
${ }^{26}$ Ibidem.

27 Ibidem.

28 Ibidem.

29 Ibidem.

30 Jako przykład podawał Matżeństwo Wobicy Krzywickiej.

31 A. Bocheński, Zygzakiem przez prasę, „Bunt Młodych”, nr 11 z 25 V 1935 r., s. 5. Na marginesie: w tekście tym Bocheński zwrócił uwagę na tygodnik „Prosto z Mostu”, dostrzegając w nim zalety „Wiadomości Literackich” bez ich wad.
} 
pchnie wszystkie w Polsce żywioły młode i zdrowe ku Wschodowi, i „dlatego - kwitował Aleksander - atakujemy «Wiadomości...» nie przeciw, ale w imię Zachodu" ${ }^{2}$. Do wymienionych już grzechów „Wiadomości...” Bocheński dodawał jeszcze znaczący wpływ na ukształtowanie będącego na bakier z logiką, ale mimo to silnego w Polsce prądu myślowego, starającego się każdą walkę nacjonalizmów wytłumaczyć jakimś konfliktem interesów materialnych ${ }^{33}$.

Podsumujmy, raz jeszcze oddając głos Bocheńskiemu:

Jak nie możemy sobie wyobrazić Polski bez wielkiego ruchu religijnego, tak nie możemy jej sobie wyobrazić bez dyscypliny społecznej, bez solidaryzmu gospodarczego i wspólnej pracy wszystkich klas dla narodu i państwa, bez kultu dla naszych wielkich tradycji, bez kultu dla naszej armii, bez pogardy dla sybarytyzmu, nihilizmu, pacyfizmu, materializmu, walki klas, tego wszystkiego, co z bliska lub daleka trąci wschodem i niewolnictwem.

Oto dlaczego położona jest nieprzyjaźń między nami a ,Wiadomościami Literackimi”. Oto dlaczego toczyć musimy z nimi nieubłaganą i bez odchyleń walkę o rząd dusz młodego pokolenia ${ }^{34}$.

Spór ideowy przeradzał się czasem w ostre starcie personalne. W wrześniu 1935 roku Bocheński poczuł się sprowokowany stwierdzeniem Słonimskiego o panującym rzekomo w „Buncie...” „erotycznym zapaszku”. „Archanioł czystości - kpił Aleksander - gromi nasze zepsucie". Większą uwagę zwracał natomiast na intelektualną i moralną nieuczciwość Słonimskiego. Przypominał, że „Bunt...” stawia pewne sprawy wyżej niż partykularny interes polityczny czy ekonomiczny: „Bunt...” potępił pogromy w Rzeszy, mimo że pragnie zgody z Niemcami, i mimo że symbioza z Żydami nie zawsze jest Polakom miła. Słonimski przeciwnie -

[...] nigdy nic nie napisał, co by nie było dyktowane jego własnym, nacjonalistycznym interesem żydowskim. Słonimski nie jest, jak Feldman, który zginął przy obronie Lwowa, [...] Polakiem pochodzenia żydowskiego. [...] nie jest, jak chaluce palestyńscy lub ortodoksi małomiasteczkowi, żydem jawnym. Słonimski ma za religię pacyfizm. On nawoływał do wojny (tak! do wojny!) z Niemcami. Słonimski ma za narodowość humanitaryzm, on cieszył się, że prześladowania katolików w Rosji doprowadzą do zwycięstwa socjalistycznego rozsądku nad „przesądami”. On, który tak krzyczy na Berlin - milczał za Kijów, i Sołowki, i Berezę. Tu jest cały Słonimski. Dwoistość, oportunizm, geszeft ${ }^{35}$.

Szczególnie bolesny był fakt, że wśród publicystów robiących za katolicki i imperialistyczny parawan dla występów Słonimskiego et consortes byli przyjaciele Bocheńskich, bracia Pruszyńscy ${ }^{36}$. Aleksander uważał to za kolosalny błąd taktyczny w stosunku do grupy „Buntu...” i w stosunku do spraw, których „Bunt...” bronił. „Wciągnięcie najlepszych naszych sił w rydwan «Wiadomości Literackich» odbiera nam zupełnie żądło narodowe polskie, w pewnym znaczeniu" - tłumaczył Mieczysławowi. Przypominał, że nacjonaliści (w szerokim rozumieniu tego słowa, a więc zarówno endecy, jak i imperialiści z „Buntu...”) odsądzają „Wiadomości...” od

\footnotetext{
A. Bocheński, Oskarżamy „,Wiadomości Literackie”, s. 1-2.

33 Idem, Inteligencja wobec chłopów, „Bunt Młodych”, nr 18 z 20 IX 1935 r., s. 4.

34 Idem, Oskarżamy ,, Wiadomości Literackie”, s. 1-2.

35 Idem, Oko w oko ze Słonimskim, „Bunt Młodych”, nr 18 z 20 IX 1935 r., s. 6.

36 Idem, List otwarty, „Bunt Młodych”, nr 2 z 10 II 1936 r., s. 1.
} 
polskości, odmawiają im prawa wypowiadania się o polskich sprawach, „kładą za nawias dyskusji” ${ }^{37}$. W związku z tym, na przykład, poruszanie na ich łamach sprawy ukraińskiej bardziej jej szkodzi, niż pomaga, bo pozwala zwolennikom polityki przeciwnej ustawiać proukraińskich publicystów „Buntu...” w jednym szeregu $\mathrm{z}$,masonami, żydami i bolszewikami” z „Wiadomości...”. „Monopolizacja sprawy ukraińskiej przez nas i Bączka ${ }^{38}$ - pisał Bocheński - a więc przez obóz antyrosyjski, dodawała kolosalnej siły nam, a w zupełnie innym świetle przedstawiała ukrainofilów, aniżeli obrona przez pismo liberalne, które kryteriów politycznych w żadnych sprawach nie uznaje" 39 .

Przez pewien czas próbował namówić Pruszyńskich do porzucenia Grydzewskiego, ustąpił dopiero wobec argumentu o konieczności finansowej (życiowej) i ze smutkiem przyjął do wiadomości, że „[...] żydłaki uważają Ksawcia już kompletnie za swego, co jest [...] kompromitujące zarówno dla nas, jak i dla niego"40. W drugiej połowie lat 30. Ksawery, w oczach Aleksandra, przeobraził się z poputczika w bezpośredniego już propagatora komunizmu, co Bocheński kładł zresztą na karb jego zagubienia i słabości charakteru. Dzielił się przemyśleniami ze starszym bratem:

Przekonania tak często zmienia, że w ogóle na serio brać tego człowieka nie można. Napisałbym, co o tym myślę, w gazetach, ale dawna moja przyjaźn z nim nie pozwala mi na to. Kiedy ulubiony pies dostanie wścieklizny, to trudno go zabić własnoręcznie. Ale też nie wolno pozwalać, aby latał swobodnie i zarażał wszystko naokoło ${ }^{41}$.

Zważywszy wszystko, co wiemy o stosunku Bocheńskiego do „Wiadomości...”, ze zdumieniem odkrywamy, że dostrzegał on na polskiej scenie ideowo-politycznej byty jeszcze gorsze, czemu dał wyraz, usłyszawszy o pomysłach Ksawerego na porozumienie ze Stanisławem Kotem. Kot to przecież czołowy morżowiec - thumaczył znowu Mieczysławowi - a więc przedstawiciel kierunku w stu procentach wrogiego, jeśli chodzi o stosunek do Rosji, stosunek do Czech i stosunek do walki z anarchią, a w tych sprawach na żadne kompromisy iść nie można. „Już lepiej z dwojga złego -

37 Aleksandra oburzało na przykład rozpisanie przez Polską Akademię Literatury (składającą się w dużej części z wyznających antynarodowy światopogląd publicystów „Wiadomości...”) konkursu na... hymn narodowy. A. Bocheński, Zygzakiem przez prasę, „Bunt Młodych”, nr 9 z 20 IV 1935 r., s. 7-8.

38 To jest Włodzimierza Bączkowskiego, redaktora „Biuletynu Polsko-Ukraińskiego”.

39 ARB, List A. Bocheńskiego do M. Pruszyńskiego [b.d.].

40 ARB, List A. Bocheńskiego do M. Pruszyńskiego z 10 III 1938 r.

41 ARB, List A. Bocheńskiego do J.M. Bocheńskiego z 11 II 1937 r. „Nie wiem, czy czytałeś jego reportaże - pisał Aleksander. - Są tam zachwyty pełne entuzjazmu dla akcji niszczenia kościołów i klasztorów. Są peany na cześć jakichś milicjantek o podejrzanej konduicie, które porównuje Prusz. do Joanny d'Arc (dosłownie). Entuzjastycznie wspomina rozstrzelanie jeńców. Cielęce zachwyty nad bolszewikami polskimi, którzy wołają z uniesieniem: «Jest Rosja! Jest Stalin!» (dosłownie), a to jako główne źródło siły i pociechy tych przyjemniaczków. Ten reportaż był tak bolszewicki, że nawet nasza cenzura skonfiskowała go w całości. Od tego czasu Prusz. rejteruje, ale nie można mówić o jego przekonaniach przed przeczytaniem reportaży we Wiad. Lit.”. 
kwitował Bocheński - aby [Ksawcio] pisywał w tej parszywej szmacie «Wiadomości Literackich», niż żeby nadskakiwał targowiczanom z frontu morges" ${ }^{\prime 2}$.

„Wiadomości Literackie” nie były złem samym w sobie, ale forpocztą ideologii zagrażającej nie tylko Polsce, ale całemu światu - komunizmu. Aleksander nie zgadzał się z tezą Ksawerego, że dla ideowych komunistów można mieć szacunek; „dla nas to nie przekonanie, to zbrodnia" - deklarował w $1936^{43}$. Uważał, że fenomen bolszewii oceni we właściwej perspektywie dopiero następne pokolenie, nieobciążone balastem zakłamania i propagandy. Podkreślał, że nie jest to ruch nacjonalistyczny, ale religijno-mistyczny; jego sprzymierzeńcami są nie wszyscy Rosjanie, ale wszyscy komuniści. Zwracał uwagę na planowość ich działania: gdy młodzież w Polsce czy Francji zatruwana jest pacyfizmem, nowi janczarzy w samej bolszewii wychowywani są do walki i podboju ${ }^{44}$.

Dla Polski przewidywał rolę przedmurza broniącego cywilizowanego świata przed infekcją komunistyczną. Za szczególnie odrażającą uważał praktykę pokajań, także wtedy, gdy ich autorami byli skruszeni komuniści, którzy oddali się władzom polskim (co prasa polska - zżymał się - przyjęła z „radosnym szałem”). „O pokajaniach niczyich - apelował - nigdy z tryumfem nie piszmy. Są to haniebne importy z Rosji, na które patrzeć trzeba z litością czy pogardą, nigdy zaś z entuzjazmem"45.

Zbliżenia z bolszewią wzbraniać miała polska racja stanu, ale nawet gdyby było inaczej, Bocheński gotów był ponad interes państwa (choć gdzie indziej przyznawał mu bezwzględne pierwszeństwo ${ }^{46}$ ) postawić w tym wypadku elementarne poczucie dobra i zła. Zapewnienia, że Polskę i Sowiety dzieli nieprzyjaźń, wymagać miało nie tylko „sumienie Rzeczypospolitej”; „dla nieszczęśliwej Ukrainy, dla bohaterskiej Gruzji - pisał Aleksander - trzeba, aby ktoś wreszcie powiedział, to co myślą wszyscy: nie jesteśmy i nie będziemy z Bolszewią" ${ }^{47}$.

Na konieczność walki z bezwzględną i powszechną propagandą bolszewicką Bocheński zwracał uwagę już w 1926 roku, u progu swej działalności publicystycznej (można wręcz uznać to za jeden z najważniejszych motywów jej rozpoczęcia) ${ }^{48}$. Przekonanie o kluczowym znaczeniu tej kwestii zachowywał 10 lat później, wskazując stosunek do komunizmu jako wyznacznik najważniejszego podziału społeczeństwa w obliczu nadchodzącego przełomu, jakim dla Europy będzie ostateczna rozprawa z bolszewizmem. „Do jednego z obozów należy cała Rosja, do drugiego całe Niemcy, w innych krajach linia graniczna przechodzi przez żywy organizm

42 ARB, List A. Bocheńskiego do M. Pruszyńskiego z 10 III 1938 r. „Polityka” często atakowała Front Morges, głównie piórem Adolfa Bocheńskiego; R. Habielski, op. cit., s. 123.

43 A. Bocheński, Młoda Polska postapi jak Młoda Japonia, „Bunt Młodych”, nr 11 z 25 VI 1936 r., s. 6-7.

44 Por. idem, Nie, nie jesteśmy w przyjaźni z Bolszewja, „Bunt Młodych”, nr 45 z 20 VIII 1933 r.

45 Idem, Śliwka i Kraus, „Polityka”, nr 28 z 10 XII 1938 r., s. 8. Przeciw pokajaniom występował także w: idem, Notatki polemiczne. „, Kurjer Poranny”, „Słowo”, nr 185 z 7 VII 1937 r., s. 3.

46 A. Bocheński, S. Łoś, W. Bączkowski, Problem polsko-ukraiński w Ziemi Czerwieńskiej, Polityka, Warszawa 1938, s. 10.

47 A. Bocheński, Nie, nie jesteśmy w przyjaźni z Bolszewja, „Bunt Młodych”, nr 45 z 20 VIII $1933 \mathrm{r}$.

48 Idem, Do pracy!, „Głos Zachowawczy”, nr 2 z 15 XII 1926 r., s. 3. 
państwowy"49 - pisał Aleksander. W Polsce ta linia, choć słabo zarysowana, przesuwała się na korzyść Moskwy, ergo na niekorzyść polskiej racji stanu.

Było to wynikiem żmudnej, wieloletniej pracy wielu środowisk, wśród których prym, jeśli chodzi o staż, poziom intelektualny i wpływy, wiodły „Wiadomości Literackie" ${ }^{50}$. (Mniejsza o to, jak bardzo świadomie; Aleksander porównywał Słonimskiego do Kiereńskiego, który przecież też nie był agentem bolszewickim) ${ }^{51}$. Do podobnych dobrze zakamuflowanych probolszewików Bocheński zaliczał schowaną pod protektoratem Rydza-Śmigłego Polską Akademię Literatury, „podrywającego autorytet militaryzmu" Emila Zegadłowicza, szerzące kult dla Moskwy w szkołach Związek Nauczycielstwa Polskiego i „Płomyk”52, wreszcie „podskakującego” przed każdym nowym premierem Wincentego Rzymowskiego.

Notabene do tego ostatniego Aleksander żywił odrazę większą nawet niż do Słonimskiego (choć zaliczał ich obu do jednej „kliki moskalofilów i szabesgojów”53). Sprowokowany atakiem Rzymowskiego na „Bunt...”54 odpowiedział w 1936 szeregiem zarzutów: udziału w zjeździe „czerwonych” pisarzy we Lwowie, deprawowania dzieci, plagiatów. Nie zgadzał się z argumentem wysuniętym przez innego publicystę „Buntu...”55, że Rzymowski jest pożyteczny, ponieważ kompromituje lewicę; jako członek PAL kompromituje on bowiem całą Polskę ${ }^{56}$. Polemikę z nim uważał za uwłaczającą autorowi i pismu, prowadził ją jednak już wcześniej i kontynuował w dwóch kolejnych przeglądach prasy ${ }^{57}$.

$\mathrm{Na}$ tak przygotowanym gruncie wyrastały ugrupowania skrajnie komunizujące, „wschodnie” i prosowieckie, w postaci przede wszystkim Legionu Młodych ${ }^{58}$. W tym przypadku nie mieliśmy już do czynienia z działalnością kryptobolszewicką, ale $\mathrm{z}$ jawnym zalewaniem kraju komunistyczną propagandą przez wielkie stronnictwo (stronnictwo - podkreślał Bocheński - a nie organizację młodzieżową czy akademicką), poczęte w cieniu BBWR, i choć oddalające się odeń w miarę nabierania sił, cieszące się ciągle niewątpliwym poparciem sfer oficjalnych, dysponujące potężnym (i kosztownym) aparatem prasowym (Bocheński wyliczał dziewięć podstawowych

49 Idem, Panie Premjerze za burtę!, „Bunt Młodych”, nr 20 z 10 XI 1936 r., s. 2.

50 Idem, Oskarżamy ,Wiadomości Literackie”, s. 1-2.

51 Idem, Zygzakiem przez prase, „Bunt Młodych”, nr 10 z 13 V 1935 r., s. 8.

52 Idem, Panie Premjerze za burtę!, s. 2.

53 Idem, Oczyścić prasę, „Bunt Młodych”, nr 7 z 25 IV 1936 r., s. 8.

54 W. Rzy mow ski, Związek Zawodowy Młodych Hrabiów, ,Kurier Poranny”, nr 309 z 6 XI 1936 r.

55 Wincenty Rzymowskj, „Bunt Młodych”, nr 20 z 10 XI 1936 r., s. 7. Artykuł niepodpisany, ale, co ciekawe, list Adolfa Bocheńskiego do O. Światopełk-Zawadzkiej z 16 XI 1936 r. (ARB) sugeruje, że autorem był sam Aleksander. Mielibyśmy więc do czynienia z kuriozalną sytuacją, w której Aleksander w kolejnym numerze „Buntu...” polemizuje z własnym niepodpisanym artykułem z poprzedniego numeru (chyba że wyjaśnienie kryje się w błędnej dacie listu).

56 A. Bocheński, [List otwarty w sprawie polemiki z W. Rzymowskim], „Bunt Młodych”, nr 21 z 25 XI 1936 r., s. 1.

57 Idem, Ordynarna demagogja, „Bunt Młodych”, nr 19 z 25 X 1936 r., s. 2; idem, Zygzakiem przez prasę, „Bunt Młodych”, nr 21 z 25 XI 1936 r., s. 8; idem, Zygzakiem przez prasę, „Bunt Młodych”, nr 23 z 25 XII 1936 r., s. 8.

58 Idem, Oskarżamy ,Wiadomości Literackie”, s. 1-2; [idem], Zygzakiem przez prasę, „Bunt Młodych", nr 10 z 13 V 1935 r., s. 8. 
tytułów, nie licząc pomniejszych). Na łamach tych pism Legion propagował program, obejmujący uspołecznienie wielkiego przemysłu, komunikacji, zakładów użyteczności publicznej, wywłaszczenie majątków rolnych i kolektywizację rolnictwa, likwidację prywatnego handlu, monopolizację handlu zagranicznego i banków ${ }^{59}$.

Do ruchu neobolszewickiego - uważał Bocheński - ciągną ludzie, których łączą trzy rzeczy. Po pierwsze, materializm historyczny, czyli przekonanie, że „[...] wszelkie przejawy polityczne, kulturalne i społeczne są, albo powinny być, powodowane przez walkę klas. Bóg, naród, patriotyzm, wolność, tradycje, to wszystko narkotyki. Prawdziwym motorem jest głód z jednej strony, chęć zysku z drugiej” ${ }^{60}$. Materialistą historycznym - kontrował Bocheński - może być tylko ignorant historyczny, tylko człowiek ślepy na problemy współczesności; postawy gdańszczan i Ukraińców, których obiektywnie rozumiany interes materialny nakazywałby jak najlepsze stosunki z Polską, są najlepszym dowodem, że teoria materializmu jest fałszywa.

Po drugie, neobolszewików łączy dążenie do upaństwowienia całego życia prywatnego, a wręcz upaństwowienia dusz (stąd ich atak na Kościół). Dla Bocheńskiego niepojęte było, jak mogą postulat ten łączyć z kultem dla nauki i techniki, skoro właśnie „nauka ekonomii dobrobytu i technika administracji wykazują niszczycielską działalność planowości fiskalnej i monopolowej, której smutny posiew w postaci kryzysu zbiera dziś świat cały"61.

Po trzecie wreszcie, młoda lewica sanacji przyciągała wszystkich chętnych do „okrycia się nazwą legionową”. „Co dzień [...] chowają kościotrupy swoich skopiowanych z Rosji programów w szary płaszcz Piłsudskiego"62 - pisał Bocheński. „Jest coś bezmiernie odrażającego w tym problemie, coś, co nie pozwala doń się zbliżyć, albo [...] każe nam zbliżyć się z rozpalonym żelazem w ręku"63. Oportunistom podszywającym się pod bohaterów zapowiadał, że kiedyś zostaną „zrzuceni ze schodów polityki polskiej".

Za publicystą „Przeglądu Katolickiego” Bocheński zwracał uwagę na schizofrenię państwa polskiego, które jednych komunistów pakuje do więzień, a innych proteguje. Nie podpisywał się jednak pod postulatem „wyrównania” tego stanu rzeczy.

Ludzi tych nie trzeba tropić, nie trzeba gnębić. [...] trzeba czekać, aż znajdą się wśród nich wszyscy zwolennicy materializmu historycznego głusi i ślepi na wielką epokę, w której żyjemy. [...] trzeba pozwolić skupić się wszystkiemu, co nienaukowe, zacofane, napompowane tanimi frazesami. A wreszcie wołamy, by w imię czegoś znacznie większego dano im jeszcze swobodny rozwój. Niech do organizacji tych dostaną się wszyscy mali ludzie podszywający się pod wielką legendę.

Niech się zbierają, niech wrzód pęcznieje. Będziemy trzymać rękę na pulsie tego nowotworu i wyciśniemy go precz, gdy nadejdzie chwila na to.

\footnotetext{
59 Idem, Dać im swobode,, „Bunt Młodych”, nr 1 z 20 I 1934 r., s. 1.

60 Ibidem.

61 Ibidem.

62 Idem, Materjalizm dziejowy, „Bunt Młodych”, nr 4 z 5 III 1934 r., s. 1.

63 Idem, Dać im swobodę.
} 
Oto dlaczego przeciw komunizmowi oficjalnemu nie chcemy mobilizować policji, ale mobilizujemy i mobilizować będziemy opinię publiczną niezależnej, niezgangrenowanej polskiej inteligencji ${ }^{64}$.

Jednym ze sposobów działania miał być wspólny front młodych imperialistów, narodowców i katolików, do którego Bocheński zapraszał wszystkich, którzy za cel nadrzędny stawiają sobie potęgę Rzeczypospolitej. To miało odróżniać front antykomunistyczny od wszelkich grup młodych radykałów lewicowych, którzy - i to rozróżnienie Aleksander szczególnie podkreślał - stawiają zmiany ustrojowe przed potęgą państwa ${ }^{65}$.

„Bunt...”/,Politykę” i sojuszników widział w segmencie prasy „niezależnej, to jest popierającej generalną linię władzy, ale zasadniczo rzeczowo usposobionej i oferującej konstruktywną krytykę, mającej pomóc, a nie szkodzić rządowi - jak krytyka prasy „opozycyjnej”, której zarzucał szukanie dziury w całym i krytykę dla krytyki. Odróżniał też prasę „,rządową”, oskarżaną z kolei o tromtadrację i hurraoptymistyczne zakłamywanie rzeczywistości, zaślepiające przede wszystkim samą władzę, a dla państwa i (niezbyt stabilnego emocjonalnie) narodu polskiego podobnie niebezpieczne, jak panikarstwo prasy opozycyjnej ${ }^{66}$.

Choć w lipcu 1937 roku wystąpił w obronie redakcji „Czasu”, poddanej szykanom pod absurdalnym pretekstem (podanym przez „Kurier Poranny”) rzekomego „rozminięcia się” z kierunkiem konserwatywnym, który miała reprezentować ${ }^{67}$, to nie odrzucał z zasady interwencji administracyjnych. W 1938 roku bronił dekretów prasowego i o ochronie interesów państwa, widząc w nich instrumenty zwalczania panikarstwa i upominając się jednocześnie o dekret przeciw tromtadracji i zakłamaniu $^{68}$. W kolejnym roku stwierdzał, że rząd konfiskujący „odbrązownicze wyczyny” niepoważnych historyków oddałby usługę kulturze polskiej (dodajmy, że chodziło o Niemcewicza od przodu $i$ tyłu Zbyszewskiego, którego Bocheński określił mianem ,hipertrofii boyizmu”, to jest łączenia złośliwego stosunku do historii polskiej z kolosalnym przerostem rysów seksualnych w charakterystykach ludzkich, dającego w rezultacie zdeformowany obraz przeszłości) ${ }^{69}$.

Może to też świadczyć o stopniowym poszerzaniu się zakresu interwencji, które Bocheński uważał za dopuszczalne, i słabnięciu początkowego idealizmu. Opinia publiczna, a szczególnie młoda generacja, pozostawały adresatem wezwań do oczyszczenia prasy z figur w rodzaju Rzymowskiego czy Słonimskiego ${ }^{70}$, ale wezwania te były coraz ostrzejsze. Już w 1933 roku zdarzało się Bocheńskiemu prasowym przeciwnikom zapowiadać, że „na razie” prawo głosu, którego bezczelnie

64 Ibidem.

65 Idem, Mocarstwowość i Marksizm, „Bunt Młodych”, nr 9 z 25 V 1936 r., s. 7.

66 Idem, Ani panikarstwo, ani zaktamanie, „Polityka”, nr 28 z 10 XII 1938 r. Zob. także: [idem],

Łamać kręgostup - to zła pedagogja, „Słowo”, nr 179 z 1 VII 1937 r., s. 1.

${ }_{67}$ Ibidem; idem, Notatki polemiczne, s. 3.

68 Idem, Ani panikarstwo, ani zaktamanie, ,Polityka”, nr 28 z 10 XII 1938 r.

69 Por. idem, Boy w karykaturze, „Polityka”, nr 5 z 10 III 1939 r.

70 Idem, Oczyścić prasę; idem, [List otwarty w sprawie polemiki z W. Rzymowskim]; idem, Zygzakiem przez prasę, „Bunt Młodych”, nr 21 z 25 XI 1936 r., s. 8. 
nadużywają, zawdzięczają panującemu liberalizmowi, ale jeżeli to się zmieni, to na gorsze dla nich ${ }^{71}$. W 1936 roku obrońców „Płomyka” wzywał, by się opamiętali (Bocheńskiego szczególnie wzburzyło „sączenie wschodniej zarazy w dusze dzieci”) ${ }^{72}$ i nie szukali guza, nie prowokowali polskiej opinii publicznej, która przy całej swej za daleko idącej cierpliwości ,już wre i czeka, aby załatwić się krótko z bolszewicką propagandą" 73 .

Reakcja opinii nie mogła być jednak zadowalająca, skoro pod koniec 1936 roku do adresatów antykomunistycznych filipik naszego bohatera dołączył premier, którego Bocheński wzywał do oczyszczenia oświaty, kultury i prasy z bolszewickiego balastu ${ }^{74}$. To jednak też nie przyniosło rezultatu, i w marcu 1937 roku Aleksander pisał o rosnącym niepokoju, z jakim opinia narodowa i katolicka patrzy na bezkarność „Wiadomości Literackich”75.

W ramach walki z ruchem krypto- i neobolszewickim Bocheński sporo uwagi poświęcał ofensywie antyreligijnej, za której reprezentantów uważał, obok „Wiadomości...” i Legionu Młodych, „Kurier Poranny”, „Epokę” i „Przełom”. Pisma te potrafiły nadać sobie sznyt „nowoczesności” i „europejskości” (,rzecz możliwa tylko w Polsce" - komentował Bocheński ${ }^{76}$, do pewnego momentu nie budziły jednak większych obaw. „Katolicyzm polski obrony nie potrzebuje - pisał Aleksander w 1934 roku. - Nie jest tak słabym, jak się to wydaje"77.

Stopniowo jednak ta pewność słabła. U progu 1937 roku Bocheński, oburzony bezkarnością redaktorów „Płomyka” i groźbami, jakie pod adresem społeczności katolickiej ośmielają się formułować „Wiadomości...”, pytał na łamach „Polityki”: „Czy naprawdę nie czas powiedzieć sobie, że Polska jest krajem katolickim [...]?”78. Kilka miesięcy później narastające obawy Aleksandra w pełni obnażył incydent wawelski, czyli przeniesienie przez arcybiskupa Sapiehę trumny Józefa Piłsudskiego z Krypty Świętego Leonarda pod Wieżę Srebrnych Dzwonów, i jego pokłosie.

Bocheńskiego zaskoczyła skala antyklerykalnej propagandy, jaka ujawniła się na przełomie czerwca i lipca 1937 roku, i wywołanej przez nią antykościelnej histerii. Poważnie niepokoił się perspektywą laicyzacji Wawelu, a nawet zerwania konkordatu. Decyzję arcybiskupa Sapiehy oceniał jako fatalną, zgadzał się nawet, że duchowny powinien za nią zostać jakoś ukarany, choć publicznie głoszone stanowisko starał się pod tym względem stonować ${ }^{79}$. Na dalej idącą krytykę pozwalał sobie w prywatnym (częściowo zachowanym) liście do siostry, w którym posunięcie Sapiehy nazywał „makabrycznym tańcem z trumną”; działanie wrogów katolicyzmu - oceniał -

\footnotetext{
11 Idem, Nasze nie ich..., „Bunt Młodych”, nr 43 z 15 VII 1933 r.

Idem, Oczyścić prasę.

Idem, Ordynarna demagogja.

Idem, Panie Premjerze za burtę.

Idem, Zygzakiem przez prase,,„Polityka”, nr 6 z 10 III 1937 r., s. 8.

Idem, Nasze nie ich...

Idem, Oskarżamy ,, Wiadomości Literackie.

78 Idem, Zygzakiem przez prase, „Polityka”, nr 4 z 10 II 1937 r., s. 8.

79 Idem, Czemu Wieniawa nie strzegl, jak wierny syn, tej trumny?, „Słowo”, nr 174 z 26 VI
}

1937 r., s. 1, 2. 
[...] nie osłabiło tak silnie Kościoła jak to jedno głupstwo. „Słowo”, konserwatyści wileńscy i nasze skromne osoby pracowały w miarę sił, aby Piłsudskiego zrobić ober-Polakiem, wydobyć jego kult z objęć socjalistów i nawet zrobić go symbolem i dla prawicy. Sapieha genialnym posunięciem od razu przekreślił całą robotę. Oddał Piłsudę socjałom. Teraz znowu tylko oni się oburzają, oni go bronią, oni chcą go honorować. Szkody polityczne i moralne wprost niesłychane ${ }^{80}$.

Zdaniem Bocheńskiego nie należało utożsamiać obrony Sapiehy z obroną Kościoła, ale brać przykład z prymasa Hlonda i samej Stolicy Apostolskiej, którzy odcięli się od metropolity krakowskiego, by bronić Wawelu i konkordatu. „Jesteśmy katolikami, a jednak czcimy kult marszałka - pisał do siostry. - Oto formułka, według której należało się ustosunkować do wszystkiego, co się dzieje. Obrona Sapiehy byłaby zaprzeczeniem tej formułki" ${ }^{81}$.

Na zarzut „Dziennika Porannego”, że widocznie nie jest dobrym katolikiem, skoro nie broni arcybiskupa, Aleksander odpowiadał, że wyprasza sobie takie oceny ze strony pisma, które nawet nie ukrywa radości z „bogatego plonu” afery; w zamian zobowiązywał się - nie będzie oceniał prawomyślności „Dziennika...” w ortodoksji marksistowsko-leninowsko-trockistowskiej. O decyzji Sapiehy nie sposób myśleć bez żalu - rozumował - ale nie sposób też zapominać, że prawdziwym wrogiem nie jest lekkomyślny duchowny, ale masoni ${ }^{82}$, socjaliści, naprawiacze (ogólnie rzecz ujmując - lewica), którzy jego nierozsądne posunięcie wykorzystali jako pretekst do wstrętnej kampanii przeciw Kościołowi. „Przypuśćmy, że p. Y służy w armii, która walczy z bolszewikami - pisał Bocheński na łamach „Słowa” - i że jeden z naszych generałów wyda zarządzenie w stosunku do sztandarów wojskowych, które nie będąc wcale «profanacją», jest niewątpliwie nietaktem. Czy to racja, aby cała armia rzuciła karabiny i otwarła bolszewikom drogę do Warszawy?"\$3.

Ubolewał, że choć data zamierzonego przeniesienia była znana, nie podjęto działań wyprzedzających, nie stworzono faktów dokonanych, jak pracowicie i genialnie uczył je stwarzać Piłsudski, a przez to zaniechanie dano lewicy do ręki ten ohydny atut. Skoro już jednak złe się stało, apelował o zdecydowane działania władz (przede wszystkim armii). W pierwszej kolejności należało odeprzeć szturm na Wawel - w imię poszanowania woli samego Marszałka („Piłsudski kazał się pochować na Wawelu, [...] górującym nad całą Polską katolicką, nie bezbożniczą, nie żydowską" ${ }^{84}$ ), w imię odpowiedzialności przed przyszłymi pokoleniami za wiekową tradycję Kościoła w Polsce i tradycję rycerską. Poza emocjonalnymi były też argumenty polityczne. Polska katolicka nie pogodzi się nigdy z laicyzacją Wawelu uważał Bocheński - a Polski dzisiejszej

80 ARB, List A. Bocheńskiego do O. Światopełk-Zawadzkiej z VII 1937 r.

81 Ibidem.

82 Zwraca uwagę podkreślanie przez Bocheńskiego udziału masonów, którzy przy innych okazjach nie byli przez niego tak wysuwani na pierwszy plan. ARB, List A. Bocheńskiego do O. Światopełk-Zawadzkiej z VII 1937 r.

83 A. Bocheński, Notatki polemiczne.

${ }^{84}$ Idem, Czemu Wieniawa nie strzegl, jak wierny syn, tej trumny. 
[...] nie stać na luksus nowej przepaści między władzą a ludem, między nacjonalizmem a państwem, między religią a administracją. Nie trzeba dla odrobienia czegoś, co się nie da odrobić, rozbijać raz na zawsze myśl o konsolidacji i o wielkim micie i wielkim zrywie całego narodu, skierowanym ku zgodnemu utrzymaniu i rozszerzeniu tego, co nam dał Piłsudski, a co może nam tylko odebrać... własna niezgoda ${ }^{85}$.

Im bliżej zakończenia konfliktu, tym mocniej Bocheński domagał się też spokojnego, ale stanowczego rozliczenia środowisk, które ,skorzystały z incydentu, by rozniecać w narodzie jad nienawiści i zadatek walki i rozłamu"86. Oczekiwał znalezienia winnych propagandy antyreligijnej, powołania komisji do zbadania, w jaki sposób mogło do niej dojść, ekspiacji ze strony sfer antyklerykalnych i twardej walki z bezbożnictwem. Apel ten kierował do sejmu, ale i do opinii publicznej, której zdecydowane poparcie miało być potrzebne posłom katolickim. „Rzeczpospolita musi tą mieć pewność - pisał - że nie będzie przez grupkę masonów wtrącona do walk religijnych, i że z takim trudem montowana akcja konsolidacyjna nie będzie narażona na nagłe i perfidne przeszkody" 87 .

Bocheński nie odmawiał sobie zasług w powstrzymaniu antykościelnej ofensywy środowisk lewicowych. Wobec milczenia endeków ${ }^{88}$, „IKC-a” i „Czasu”, „[...] cały ciężar obrony Kościoła leżał na «Słowie» - pisał do siostry (a przez cały okres kryzysu Aleksander zastępował w Wilnie nieobecnego Mackiewicza). - Jeśli «Słowo» mogło ten ciężar znieść do brzegu przeciwległego, to dlatego, że nie sprzeniewierzyło się ani na chwilę kultowi dla Piłsudy, którego broniło w gorszych tarapatach, i którego też nie wyrzeka się po śmierci. To zneutralizowało zupełnie ataki lewicy"89. Przy okazji ujawniła się w pełni specyfika jego stosunku do Piłsudskiego: więcej było w nim wyrachowania (kult „Piłsudy” postrzegał jako czynnik integracji społeczeństwa), mniej uwielbienia, jakie dla Marszałka żywił Mackiewicz.

Wybuch antyklerykalizmu uważał za dowód siły propagandy naprawiackiej, mimo jej relatywnie słabego umocowania w społeczeństwie:

Polska jest krajem [...] prawie wyłącznie katolickim [...], katolicyzm polski jest żywy, związek $\mathrm{z}$ duchowieństwem silny, przywiązanie do tradycji ogromne. I mimo to wszystko, z powodu fatalnego incydentu [...], nagle, jak za dotknięciem laski Mojżesza, zaczynają spadać jak gromy z jasnego nieba różne dziwne stwory antyreligijne. Nie tylko nikt nic nie robi, aby powstrzymać to szaleństwo, ale nawet wiele przemawia za tym, że pewne sfery akcję tę potęgują, chociaż

85 Ibidem.

${ }^{86}$ A.B. [A. Bocheński], Incydent wawelski zlikwidowany. Czy Sejm potępi propagandę bezbożniczą, „Słowo”, nr 182 z 4 VII 1937 r., s. 1.

87 Ibidem. Zob. także: A.B. [A. B o cheński], Sesja jest potrzebna i jasne, katolickie stanowisko na sesji, „Słowo”, nr 183 z 5 VII 1937 r., s. 1.

88 Ciekawe wspomnienie dot. „,endeckiej mentalności” zapisał Bocheński kilka lat później: „Pierwsza rzecz, jaką zrobimy - powiedział mi [Ojciec Jacek Woroniecki] w roku 1940, gdy go odwiedziłem w Krakowie - to wyrzucimy Piłsudskiego z Wawelu...”. ARB, A. B ocheński, Notatki $i$ wspomnienia rodzinne, 1940-1942, mps, s. 34.

89 ARB, List A. Bocheńskiego do O. Światopełk-Zawadzkiej z VII 1937 r. 
potęgowanie tej akcji może i musi doprowadzić [...] do stoczenia się po tej tragicznej drodze, na której znalazła się Hiszpania ${ }^{90}$.

Jednocześnie zwrócił uwagę na wyrok uniewinniający Adama Doboszyńskiego za akcję myślenicką; sędziowie przysięgli, reprezentujący autentyczny punkt widzenia szarego obywatela, uznali pogwałcenie porządku publicznego za usprawiedliwione groźną sytuacją. Bocheński uznał to za - jedno z dwojga - albo objaw kompletnego rozkładu moralnego, albo wotum nieufności do dwoistego systemu rządowo-naprawiackiego. „Werdykt przysięgłych to dzwon alarmowy” - konkludował Bocheński wzywający do dalszych starań o oczyszczenie polskiego życia państwowego i zakończenia walki, która rozdziera same jego podstawy ${ }^{11}$.

W tej walce wciąż wykuwał się warsztat myślowy i pisarski Bocheńskiego, a jego ewolucja nie przebiegała płynnie i w chwili wybuchu wojny nie była jeszcze zakończona. Jednoznacznej ocenie wymyka się też bilans przerwanej wojną dekady publicystycznych zmagań. Z jednej strony ostatnie lata II Rzeczypospolitej przyniosły ożywienie działalności grupy „Polityki”. W 1937 roku uruchomiono stałą serię wydawniczą ${ }^{92}$. Publikacjom towarzyszyły spotkania dyskusyjne, organizowane między innymi przez powołany w tym okresie przez Giedroycia Klub „Polityki”, wzorowany na Klubie 11 listopada ${ }^{93}$. O rosnących ambicjach pod koniec lat 30 . świadczy też zamiar wzięcia udziału w wyborach parlamentarnych ${ }^{94}$. Przyciągnięcie pod skrzydła „Polityki” szeregu odrębnych dotąd grup młodzieżowych o mniejszym wyrobieniu politycznym było, zdaniem Aleksandra, na wyciągnięcie ręki, rozważano też stworzenie nowej organizacji młodzieżowej, ,by zdobywać narybek" ${ }^{\prime 95}$.

Z drugiej strony bezkarność „Wiadomości Literackich” i bezczelność propagandy antykatolickiej poważnie nadwyrężyły optymistyczne przekonanie, że przyszłość należy do młodych mocarstwowców. Jeśli w pierwszej połowie lat 30 . Bocheński spodziewał się, że „Młoda Polska” z poparciem całego narodu będzie ideowych przeciwników „zrzucać ze schodów polityki polskiej”, to druga połowa dekady przyniosła bolesne rozczarowanie. Wzmagała się niepewność i irytacja żywotnością lewicy (co było szczególnie widoczne na tle reakcji na incydent wawelski) oraz pokusa, by „załatwić się z nią" nie piórem, ale metodami administracyjnymi.

90 A.B. [A. Bocheński], Werdykt przysięgtych to dzwon alarmowy, „Słowo”, nr 177 z 29 VI

1937 r., s. $1,2$.

91 Ibidem.

92 R. Habielski, op. cit., s. 30-32.

93 ARB, A. Bocheński, Odpowiedź na kwestionariusz St. Mackiewicza do biografii Adolfa Bocheńskiego, mps, [ok. 1947 r.], s. 43; R. Habielski, op. cit., s. 31.

94 R. Tomczyk, op. cit., s. 312; J. Giedroyć, op. cit., s. 60; M. Król, op. cit., s. 18; R. Habielski, op. cit., s. 32 .

95 ARB, List A. Bocheńskiego do M. Pruszyńskiego z 10 III 1938 r.; List A. Bocheńskiego do S. Łosia z 4 XII 1938 r., APL, Archiwum Łosiów z Niemiec, sygn. 463, k. 7 r-v; List A. Bocheńskiego do S. Łosia z 31 XII 1938 r., APL, Archiwum Łosiów z Niemiec, sygn. 463, k. 8 r-v (oba za: P. Libera, Z dziejów ,Buntu Młodych” $i$ „Polityki”. Listy Aleksandra i Adolfa Marii Bocheńskich do Stanistawa Eosia (1932-1939), „Studia z Dziejów Rosji i Europy Środkowo-Wschodniej” 2013, t. XLVIII, s. 327 350); ARB, List A. Bocheńskiego do M. Pruszyńskiego z 6 II 1939 r.; ARB, A. B ocheńsk i, Odpowiedź na kwestionariusz St. Mackiewicza..., s. 42-43. 
Zmagania z kliką bolszewicko-masońsko-żydowsko-bezbożniczą były zresztą zaledwie jednym $z$ frontów walki o kształt państwa i społeczeństwa. Za nie mniej ważne problemy Bocheński z pewnością uważał politykę gospodarczą, której kierownikom zarzucał duszenie możliwości rozwoju w imię zaspokojenia partykularnych interesów klasy urzędniczej ${ }^{96}$, politykę mniejszościową (szczególnie wobec Ukraińców) - którą uważał za mieszankę głupoty, absurdów i niekonsekwencji ${ }^{97}$, wreszcie „ofensywę półinteligencji polskiej przeciw szlachcie polskiej na Kresach”"98, będącą notabene fragmentem wojny, jaką ziemiaństwu wydała wszechwładna w Rzeczypospolitej biurokracja. O dziwo, najmniej zastrzeżeń budziła polityka zagraniczna (nawet mimo upadku forsowanej przez Bocheńskich linii porozumienia z Niemcami), choć już postawa społeczeństwa pozostawała o wiele za mało, jak na gust Aleksandra, antysowiecka ${ }^{99}$. Bocheński ani jednym słowem nie dał do zrozumienia, by nie uważał odrodzonej Polski za „swoje” państwo. Jednocześnie jednak nie szczędził jej najostrzejszej krytyki. „Parę wieków Rzeczypospolitej dawnej - pisał - nie zmarnowało tyle okazji [w sprawie ukraińskiej], nie okazało tyle małoduszności i ignorancji, co 15 lat naszego współczesnego społeczeństwa polskiego”100. „Państwo przez 10 lat zniszczyło bardziej ziemiaństwo, niż to mocarstwa zaborcze próbowały robić w ciągu lat $150 " 101$. Polityką gospodarczą doprowadziło najliczniejszą w Polsce warstwę chłopską na skraj ,załamania poczucia patriotyzmu i obowiązku”102.

W tym kontekście nieprzynoszące wyraźnej przewagi publicystyczne potyczki pogłębiały tylko chęć ,przewrócenia całej Polski do góry nogami [...], tj. aby przestała chodzić na głowie i aby stanęła na nogach" ${ }^{103}$. Polemiczny zapał, przyjęty $\mathrm{u}$ progu lat 30. jako rodzaj pewnej strategii budowania własnej pozycji na rynku prasowym (czy „rynku” idei) w Polsce, pod koniec dekady napędzany był w znacznie większym stopniu frustracją spowodowaną żywotnością ideowych przeciwników i brakiem postępów w oczekiwanym przez Bocheńskiego kierunku, co obok rozczarowania polityką II RP na niemal każdym polu tworzyło grunt pod światopoglądową przemianę i nowe stanowisko, jakie Bocheński zajmie po wojnie.

\footnotetext{
96 Zagadnieniom gospodarczym szczególnie wiele artykułów poświęcił na łamach „Słowa”.

97 A. Bocheński, S. Łoś, W. Bączkowski, op. cit., passim.

98 A. Bocheński, Zygzakiem przez prasę, „Bunt Młodych”, nr 10 z 13 V 1935 r., s. 8.

99 ARB, List A. Bocheńskiego do J.M. Bocheńskiego z 11 II 1937 r.

100 A. Bocheński, Zygzakiem przez prasę, „Bunt Młodych”, nr 11 z 25 V 1935 r., s. 5.

101 Idem, Rozwalmy teatr. Styl i rodzaj literacki, „Słowo”, nr 49 z 1 III 1932 r., s. 1.

102 Idem, Ratować polskich chłopów, „Bunt Młodych”, nr 14-15 z 20 VII 1935 r., s. 4, 11.

103 ARB, List A. Bocheńskiego do M. Pruszyńskiego z 10 III 1938 r.
} 


\title{
BIBLIOGRAFIA
}

\author{
Archiwa
}

Archiwum Rodziny Bocheńskich [ARB].

\section{Prasa}

„Bunt Młodych” 1933-1937.

„Głos Zachowawczy” 1926.

„Kurier Poranny” 1936.

„Polityka” 1937-1939.

„Słowo” 1932-1937.

\section{Wydawnictwa publicystyczne}

Bocheński A., Dzieje głupoty w Polsce. Pamflety dziejopisarskie, Panteon, Warszawa 1947.

Bocheński A., Bocheński A.M., Tendencje samobójcze narodu polskiego, Drukarnia Akademicka, Lwów 1925.

Bocheński A., Łoś S., Bączkowski W., Problem polsko-ukraiński w Ziemi Czerwieńskiej, Polityka, Warszawa 1938.

Jasienica P., Cień Machiawela, „Tygodnik Powszechny”, nr 31 (124), z 3 VI 1947 r.

Kieniewicz S., Nowy sąd nad historia, „Dziś i Jutro”, nr 25 (82), z 22 VI 1947 r., s. 1-2.

\section{Wspomnienia}

Giedroyć J., Autobiografia na cztery ręce, Czytelnik, Warszawa 1994.

Pruszyński M., Migawki wspomnień, Wydawnictwo „Rosner i Wspólnicy”, Warszawa 2002.

Pruszyński M., W dziewięćdziesiąta rocznicę urodzin Aleksandra Bocheńskiego, „Zeszyty Historyczne. ZNUJ" 2000, z. 134, s. 162-175.

Supruniuk M.A., Uporządkować wspomnienia. Nieautoryzowane rozmowy z Jerzym Giedroyciem, Towarzystwo Przyjaciół Archiwum Emigracji, Toruń 2011.

\section{Opracowania}

Gałka B., Konserwatyści w Polsce lat 1935-1939, wyd. uzup. i popr., Wydawnictwo Adam Marszałek, Toruń 2013. 
Habielski R., Dokąd nam iść wypada? Jerzy Giedroyć od „Buntu Młodych” do „, Kultury”, Towarzystwo „Więź”, Warszawa 2006.

Kornat M., Polska szkoła sowietologiczna 1930-1939, Arcana, Kraków 2003.

Król M., Style politycznego myślenia. Wokół „,Buntu Młodych” $i$ „Polityki”, Libella, Paryż 1979.

Libera P., Ocena polityczna grupy „Polityki” przez Oddziat II Sztabu Głównego w 1938 r., „Zeszyty Historyczne. ZNUJ” 2010, z. 171, s. 142-147.

Libera P., Z dziejów „Buntu Młodych” i „,Polityki”. Listy Aleksandra i Adolfa Marii Bocheńskich do Stanisława Łosia (1932-1939), „Studia z Dziejów Rosji i Europy Środkowo-Wschodniej" 2013, t. XLVIII, s. 327-350.

Mozgol R., Ryzykowna gra. Jak Aleksander Bocheński przyczynit się do powstania „Dziś i Jutro”, „Biuletyn IPN” 2007, nr 4 (75), s. 84-92.

Sadkiewicz J., Schemat sojuszu z silniejszym mocarstwem - Aleksander Bocheński od koncepcji proniemieckiej do koncepcji prosowieckiej [w:] Między sercem a rozumem. Romantyzm i realizm w polskiej myśli politycznej, red. A. Citkowska-Kimla [i in.], AT Wydawnictwo, Kraków 2017, s. 283-294.

Szlachta B., Z dziejów polskiego konserwatyzmu, Wydawnictwo Dante, Kraków 2000.

Tomczyk R., Myśl mocarstwowa. Z dziejów młodego pokolenia II Rzeczypospolitej, Print Group, Szczecin 2008.

Wendland W., Katon w ,krainie wielkich błaznów”. Aleksandra Bocheńskiego wizja polskości [w:] Marzyciele i realiści: o roli tradycji w polskiej myśli politycznej od upadku powstania styczniowego do XXI wieku, red. T. Sikorski, A. Wątor, Zapol, Szczecin 2009, s. 521-534.

Wierzbicki A., Wszystkiemu winni sq historycy. W kręgu myśli historycznej i politycznej Aleksandra Bocheńskiego i Andrzeja Wasilewskiego [w:] Gra i konieczność. Zbiór rozpraw z filozofii historii i historii historiografii, red. G. Dominiak, J. Ostoja-Zagórski, W. Wrzosek, Oficyna Wydawnicza Epigram, Bydgoszcz 2005, s. 155-161.

Zackiewicz G., Polska myśl polityczna wobec systemu radzieckiego 1918-1939, Arcana, Kraków 2004. 